\title{
ACUTE PULMONARY HISTOPLASMOSIS AND FIRST ISOLATION OF. HISTOPLASMA CAPSULATUM FROM SOIL OF RIO GRANDE DO SUL, BRAZIL.
}

L. C. SEVEro (1), V. F. Petrillo, J. 3. camargo, G. R. GeYer and N. S. Porto

\section{S U. M. M A R Y}

A case of acute pulmonary histoplasmosis, where the clinical history and epidemiological data led to the identification of $\mathbf{H}$. capsulatum natural source, is described. Specimens of spleen and liver, obtained after intraperitonial inoculation in mice, grew $H$. capsulatum in culture from the soil of rural area of General Câmara, by the first time in Rio Grande do Sul.

KEY WORDS: Human Histoplasmosis - LUNG - Isolation of Histoplasma capsulatum from soil.

\section{N T ROD U C TIO N}

Histoplasma capsulatum distribution in nature has received litte attention in Brazil ${ }^{10}$. The fungus had been recovered from soil associated with chicken and bat feces, in rural areas near rivers, in regions with high positivity of the skin test to histoplasmin and epidemics of the fungal infection (Table I).

A case of acute pulmonary histoplasmosis will be described where clinical history led to the identification of Histoplasma capsulatum natural source.

\section{CASE REPORT}

A 23 year-old white man in a good health until March 22, was admitted in our service with thoracic pain, fever, cough with scant expectoration, headache, anorexia, weight loss, prostation and malaise.

T A B L E I

H. capsulatum isolated from soil in Brazil

\begin{tabular}{|c|c|c|c|c|c|}
\hline Year & Association & Location & Site & Comments & Authors \\
\hline 1955 & Chickens & Jacobina, BA & $\begin{array}{l}\text { Near Ouro's } \\
\text { river }\end{array}$ & $\begin{array}{l}\text { Kala-azar } \\
\text { endernic zone }\end{array}$ & SIIVA (15) \\
\hline 1966 & Bats & $\begin{array}{l}\text { Caraguatatuba } \\
\text { and Ubatuba, SP }\end{array}$ & Beach house & $\begin{array}{l}\text { Histoplasmosis } \\
\text { epidemic }\end{array}$ & $\begin{array}{l}\text { FAVA NETTO } \\
\text { et al. (5) }\end{array}$ \\
\hline 1967 & Bats & Brasillia, DF & Rural cave & $\begin{array}{l}\text { Histoplasmosis } \\
\text { epidemic }\end{array}$ & $\begin{array}{l}\text { SCHIMIDT } \\
\text { et al. (14) }\end{array}$ \\
\hline 1967 & Chickens & Lagoa Santa, MG & Rural area & $\begin{array}{l}\text { Histoplasmosis } \\
\text { skin test of } 46 \%\end{array}$ & ARAUJO (1) \\
\hline 1975 & Chickens & Aripuanã, MT & $\begin{array}{l}\text { Near Aripuanã } \\
\text { river }\end{array}$ & $\begin{array}{l}\text { Histoplasmosis } \\
\text { skin test of } 63 \%\end{array}$ & $\begin{array}{l}\text { MORAES \& } \\
\text { ALMEIDA (10) }\end{array}$ \\
\hline I984 & Chickens & $\begin{array}{l}\text { General } \\
\text { Cāmara, RS }\end{array}$ & $\begin{array}{l}\text { Near Jacui } \\
\text { river }\end{array}$ & $\begin{array}{l}\text { Acute pulmonary } \\
\text { histoplasmosis }\end{array}$ & $\begin{array}{l}\text { SEVERO et al. } \\
\text { (present report) }\end{array}$ \\
\hline
\end{tabular}

Instituto de Pesquisas Biológicas, Secretaria da Saúde e do Meio Ambiente and Pavilhäo Pereira Fuho, Porto Alegre, RS, Brazil

(1) Pesquisador $3 \mathrm{~A}$ do CNPq 
SEVERO, L. C.; PETRILLO, V. F.; CAMARCO, J. J; GEYER, G. R. \& POIrTO, N, S. - Acute pulmonary histoplasmosis and first isolation of Fistoplasma capsulatum from soll of Riso Grande do Sul, Brazil Rev. Inst. Med. trep, Säo Paulo 28:51.55. 1946 .

On fisical examination he seemed acutely ill, with an axilar temperature $38,5^{\circ} \mathrm{C}$, pulse 82 , respiration 22 , blood pressure of $100 / 60 \mathrm{mmHg}$. Without adenomegaly neither hepatosplenomegaly. Chest $\mathrm{X}$-rays showed nodules and micronodules disseminated in both lungs, mainly in the lower $2 / 3$ fields, and probable interlobular and paratracheal adenomegaly (Fig. 1). Sputum examination was negative to acid-fast bacilli, fungus, and malignant cells. Hematocrit $33 \mathrm{ml} /$ dl, hemoglobin $11 \mathrm{~g} /$ dil, WBC 8,000 (eos 2, ban 4 , seg 53 , lynph 36 , mon 5 ).

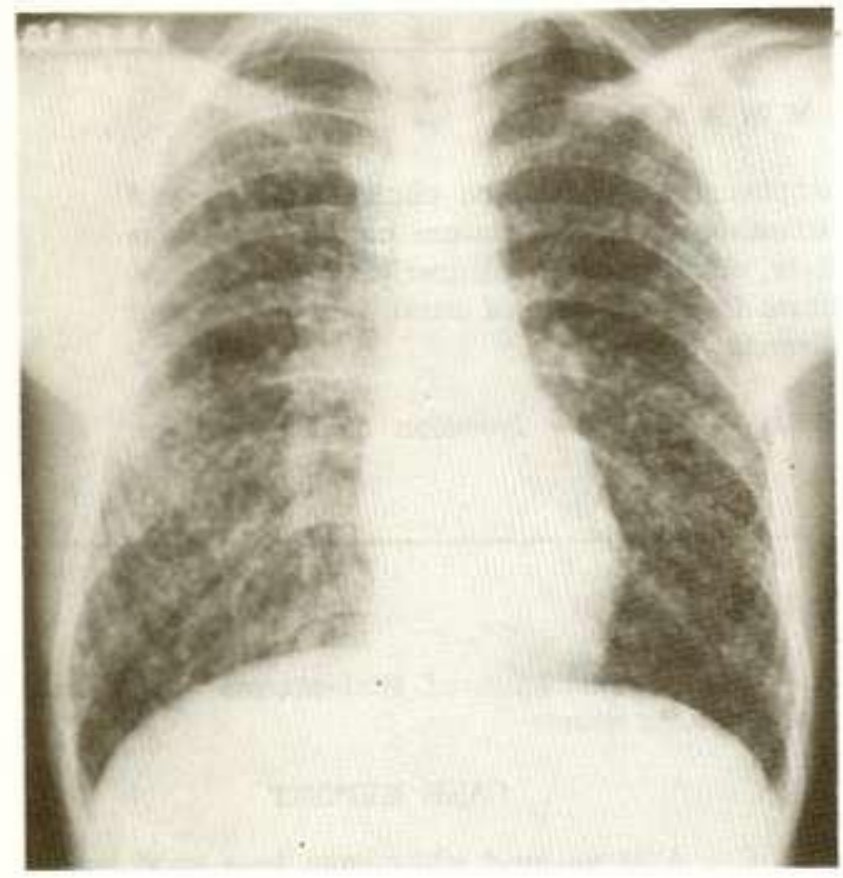

Vig. 1 - Radiologic aspects of multiple miliary nodules in both lungs with hilar adenopathy

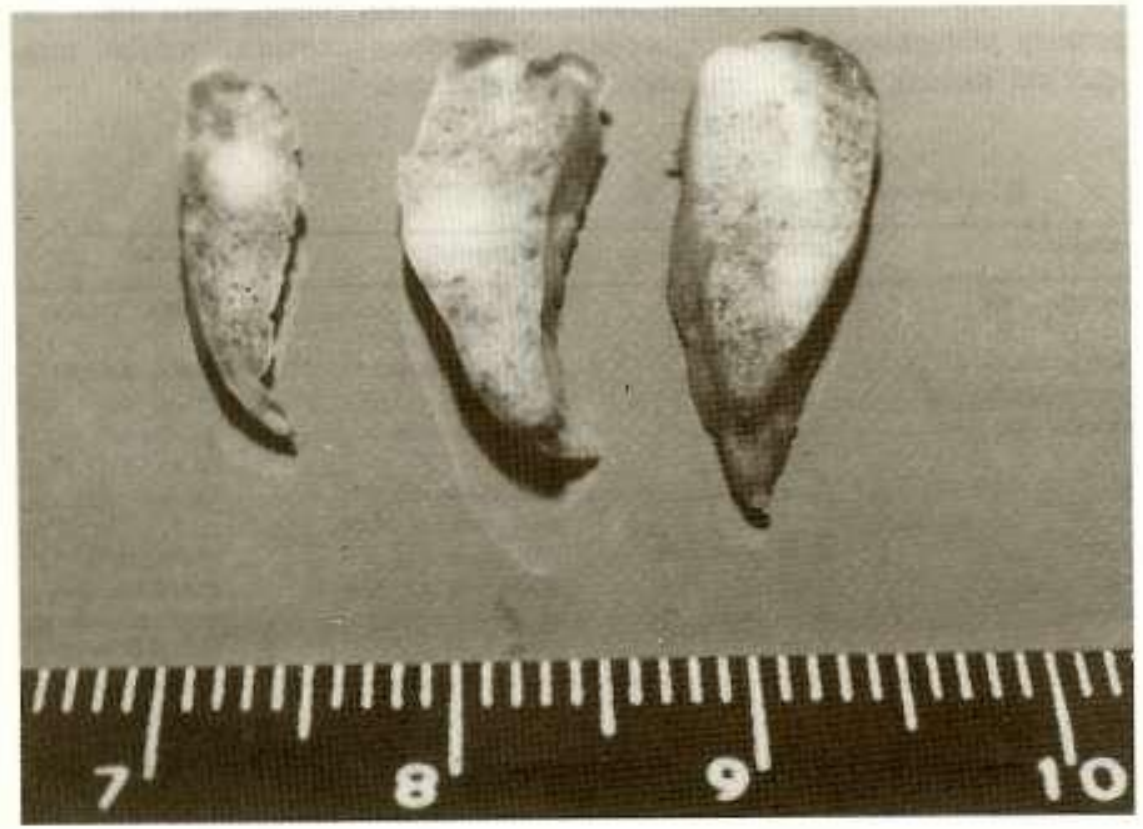

Pig. 2 - Pulmonary te sions trom biopsy after formol tixation; section demonitrate dense white nodules 


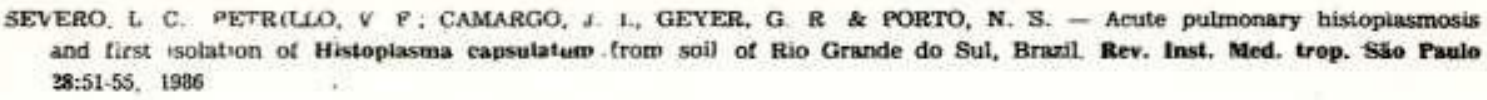

SEVERO. I C. PETRILLO, V P. CAMARGO, I. 1, GEYER, G. R \& PORTO, N. S. - Acute pulmonary histopiasmosis and first isolation of Histopiasma capsulatum . from soil of Rio Grande do Sul, Bravil Rev. Inst. Med. trop. Siso Paulo 38:51-55, 1986

With presuntive diagnosis of granulomatous pulmonary infection (specially tuberculosis and histoplasmosis) the patient was submitted to an open lung biopsy. A cuneiform tragment of lingula, measuring $2.5 \times 2,2 \times 1,0 \mathrm{~cm}$, was tixed in formalin and sent to the pathologist (Fig. 2). Another fragment of tissue specimen was recovered in a sterile tube containing, $2.0 \mathrm{ml}$ of sterile water and transported to the labo. ratory.

Pathology - The lung tissue was grey, witb white and hard nodules, measuring $0.5 \mathrm{~cm}$ iFig. 2). The haematoxylin and eosin-stained tissue section showed a tuberculoid granuloma with central caseous zone. The Gomori methenamine silver (GROCOTT) well demonstrated the one budding yeast cells of Histoplasma capsulatum. Ac1d-fast bacilli were not found.

Mycology - Under sterily conditions, with forcep and scalpel in a Petri disch a nodule was removed from the lung specimen. It was cut into small fragments with scissor and forcep.
Some of then were inoculated in Sabouraud and brain heari infusin agar and submitted to $25^{\circ} \mathrm{C}$ and $37^{\circ} \mathrm{C}$, respectively. A direct smear of a small fragment of nodule in $10 \% \mathrm{KOH}$, observed by bright-field microscopy was without evidence of microorganisms, as well as the Ziehl-Neelsen and Gram-stained smears. One week after colony development was observed. Portion of both cultures (Fig. 3) was submitted to microscopic examination and reveled the H. capsulatum in it's dimorpnism.

Mycoserology - Serum obtained after mycological diagnosis, was sent to Dr. Leo Kaufman (CDC, Atlanta, GA) who tested it for $\mathbf{H}$. capsulatum antibodies by the immunodiffusion and complement fixation tests. Both were positive, with $M$ band and at 1:64, respectively.

Epidemiology - The oriented clinical history revealed that the patient in March 9, forteen days before becoming ill, cleaned a chicken house (Fig. 4) by five hours in the rural area of General Câmara, Rio Grande do Sul,

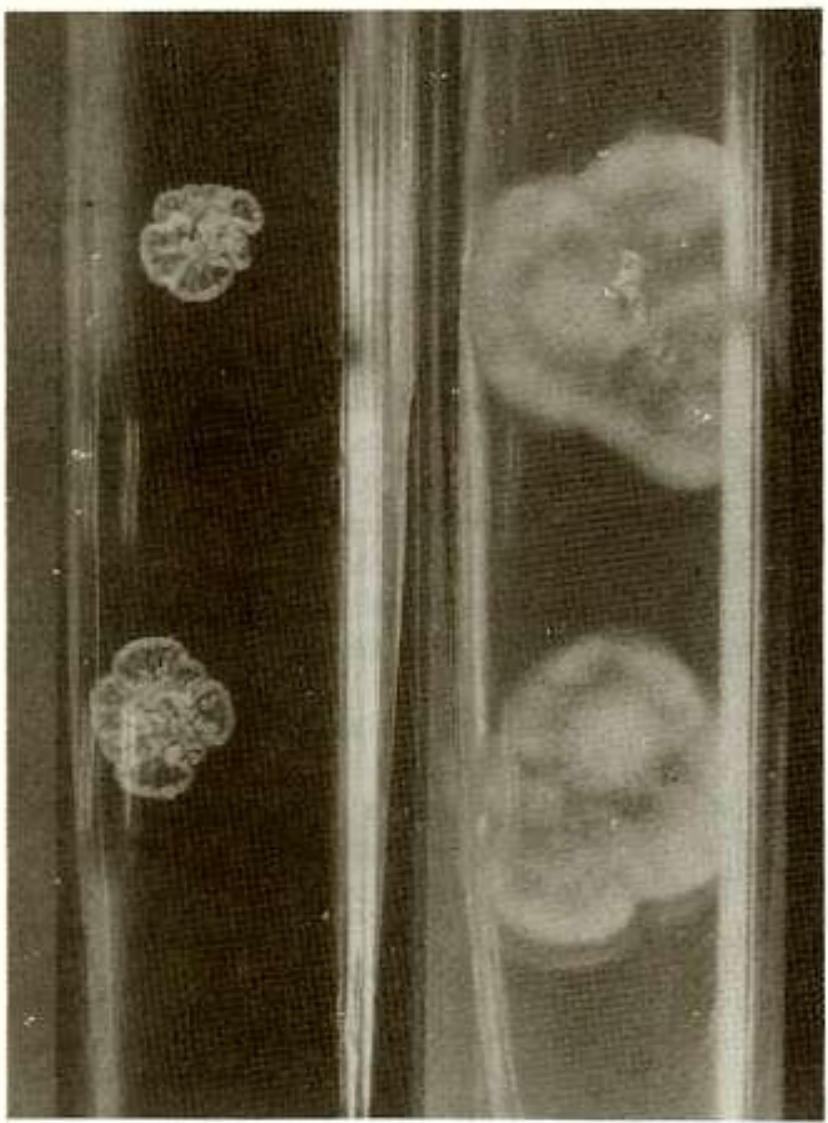

Fig. $3-$ H. capsulatum isolated from pulmonary caseous granuloms in it's dimorphism 
SEVERO, L. C.; PETRILLO, V. P.; CAMARGO, J. Ji; GEYER, G. R. \& PORTO, N. S. - Acute putmonary histoplasmosis and first tsolation of Histoplasma eapsulatem from soil of Rio Grande do Sul, Braxil. Rev. Inst. Med. trop. Sato Paulo 98:51-55, 1986 .

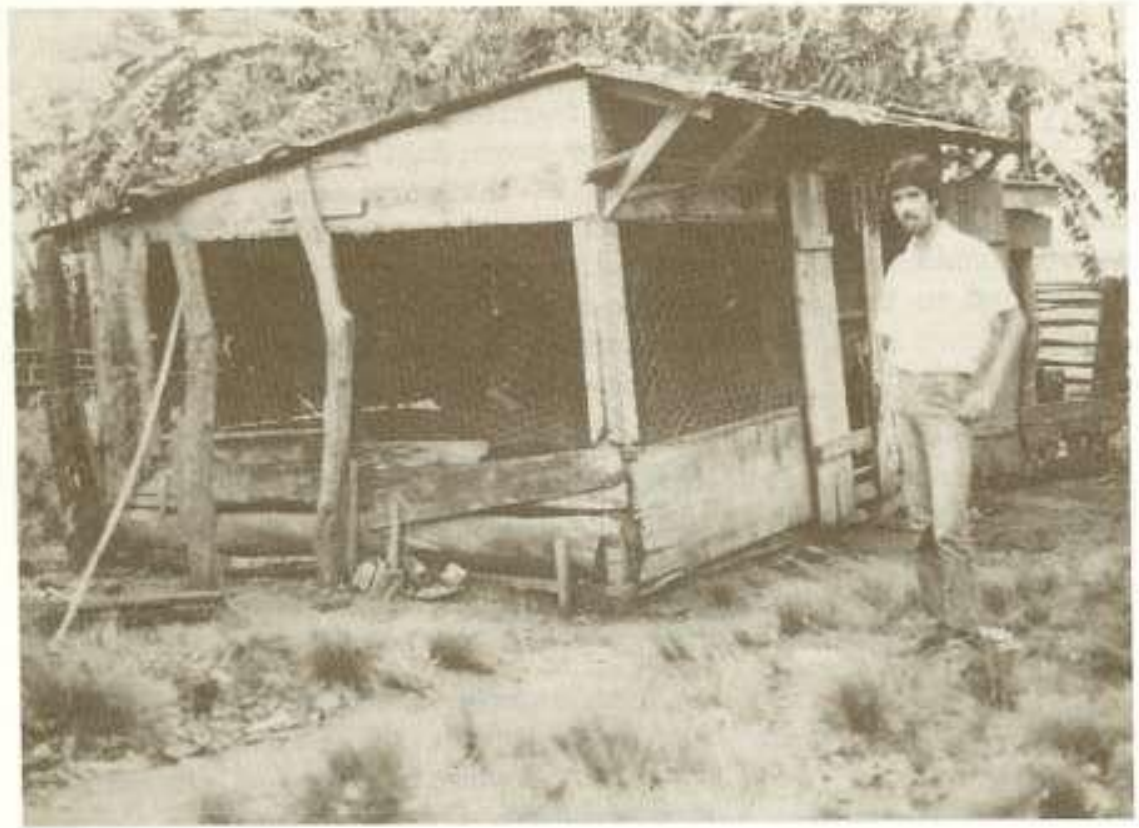

Fig. 4 - The patient by his chicken house were he contracted histoplasmosis near the Jacui river. We recovered soil samples from three parts of this place and by intraperitoneal inoculation in mice and posterior cultivation of spleen and liver fragments 4 isolated H. capsulatum. The mould-form-to-yeast-form conversion in brain heart infusion at $37^{\circ} \mathrm{C}$ was done.

Evolution - The patient returned one and six months later. He seemed to be improving symptomatically without treatment and the chest $\mathrm{X}$-rays reveled marked improvement in both opportunity. Mycoserology showed no changes in six months control.

\section{COMMENTS}

Histoplasmosis must be an important public health problem in Brazil 7 . In Rio Grande do Sul, beacuse of greater awareness 6 , there is an increase in the report of clinical cases $3,11,12,13$, and most of these cases come from the Jacui's river valley ${ }^{12,13}$, where the $\boldsymbol{H}$. capsulatum was isolated from soil and sensitization to histoplasmin is the highest, $39.1 \%$ 9. This rate of skin test positivity needs further confirmation", but is similar to Argentina's and Uruguay's valley of rivers ${ }^{8}$.

It is interesting to note that in spite of Rio Grande do Sul has similar climatic condi- tions as does Uruguay, acute pulmonary histoplasmosis has never been reported in our neighboring country ${ }^{2}$.

\section{RESUMO}

Histoplasmose pulmonar aguda e primeiro isolamento do Histoplasma capsulatum do solo do Rio Grande do Sul, Brasil

Apresenta-se um caso de histoplasmose pulmonar aguda, onde a história clínica orientada levou a identificaçāo da fonte natural do His. toplasma capsulatum. O fungo foi obtido em cultivo a partir de fragmentos de baço e figado de ratos inoculados intraperitonealmente com solo da zona rural de General Câmara, pela primeira vez no Rio Grande do Sul.

\section{ACKNOWLEDGEMENT}

Our sincere appreciation is expressed to Dr Leo Kaufman (CDC, Atlanta, GA, U.S.A.) for performing the mycoserology.

\section{REFERENCES}

1. ARAUjO, F. G. - Primeiro isolamento de Histoplasma capsulatum de solo em Minas Gerais. Rev. Inst. Med. trop. São Paulo 12: 185-191, 1970. 
SEVERO, L. C.; PETRLLLO, V. F.; CAMARGO, J. J.; GEYHR, G. R. \& FORTO, N. S. - Acute pulmonary histoplasmosis and first isolation of Histoplasma capsulatum from soil of Rio Grande do Sul, Brazil. Rev. Inst. Med. trop. São Paulo 28:51-55, 1986 .

2. CONTI-DIAZ, 1. A. \& LUZ, S. - Histoplasmosis en el Urugusy. Tórax (Montevideo) 17: 46-49, 1968 .

3. COUTINHO, L. M. B.; GELPI, A. L.; ANICET, A.; SANTIAGO, R. G.; FERNANDEZ, L. N. \& FONTANARI, J. - Histoplasmomas encefálicos Múltiplos. Estudo autópsico de um caso. Arq. Neuro-Psiquiatria 39: 340$349,1981$.

4. FMMONS, C. W. - Isolation of Histoplasma capsulatum from soll. Public Health Rep. 64: 892-896, 1949.

5. FAVA NETO, C.; Silva, U. A.; Chammas, F. \& LACAZ, C. S. - Histoplasmose epidêmica. Estudo clínico, radfológico, micológico e imunológico de surto ocorrido no Estado de São Paul, Brasil, Reev. Inst. Med. trp. Săo Paulo 9: 222-232, 1967.

6. LACAZ, C. S.; PORTO, E. \& MARTINS, J. E. C. Micologia Médica. Fungos, actinomicetos e algas de interesse médico. 7th ed., São Paulo, Sarvier, 1984, 241-253.

7. LONDERO, A. T. \& RAMOS, C. D. - The status of histoplasmosis in Brazil. Mycopathologia (Den Haag) 64: $153-156,1978$.

8. MACKINNON, J. E. - Histoplasmosis in Latin America. In: Histoplasmosis. Proc. 2nd Nat. Conf. (Ed. A.JELLO, L.; CHICK, E. W. \& FURCOLOW, M. L.). Springfield, Charles C. Thomas 1972, 129-139.

9. MARSIAJ, N.; P. Y. A. \& PEGAS, N. - Primeiras pesquisas sobre sensibllidade cutânea à histoplasmina no Estado do Río Grande do Sul. Suas relaçöes com as lesరెes pulmonares residuais. Rev. Bras. Med. 7: 157-163, 1950.

10. MORAES, M. A. P. \& ALMEIDA, M. M. R. - Isolamento de Histoplasma capsulatum do solo de Humboldt (Estado de Mato Grosso, Brasil). Acta Amazonica 6: 43-47, 1976.

11. PINOTTI, A. F. F.; SEVERO, L. C.; RANDON, M.; RIGATTO, M. \& HAASE, H. B. - Histoplasmose disseminada associada a tuberculose em pacientes imunodeprimidos. Rev. Ass, Med. Brasil. 29: 68-70, 1983.

12. SEVERO, L. C.; KAEMMMFRER, A. \& CHAIFB, J. A. Histoplasmose aguda em criança. Relato de um caso e revisão da literatura brasileira. J. Ped. 52: 237-238, 1982.

13. SEVERO, L. C.; PICON, P. D.; LONDFRO, A. T. \& RUBIAO FILHO, H. J. - Histoplasmose aguda. Ro lato de dois casos. Rev. AMRIGS 25: 64-67, 1981.

14. SCHIMIDT, S.; MACHADO, O. P. \& GaLVAO, A. B. - Microepidemía de histoplasmose na zona rural de Brasília - DF - 1967. II - Estudo epidemiológico $\theta$ parasitológico da fonte de infeç̧āo. Rev. Soc. Bras. Met., Trop. 7: 107-115, 1973.

15. SIIVA, M. E. - Isolamento de Histoplasms capsula tum do solo, em zona endêmica de calazar na Bahia, Brasil. Bol. Fund. Gonçalo Moniza 10: 1-7, 1958.

Recebido para publicaģ̄o em 11/2/1985. 